Article

\title{
Mobility, Transport and Social Inclusion: Lessons from History
}

\author{
Colin Pooley \\ Lancaster Environment Centre, Lancaster University, Lancaster, LA1 4YQ, UK; E-Mail: c.pooley@lancaster.ac.uk
}

Submitted: 2 October 2015 | Accepted: 19 January 2016 | Published: 7 June 2016

\begin{abstract}
This paper argues that although it is now possible to travel more quickly and easily than ever before, transport-related social exclusion is more likely than it was in the past. Using evidence drawn from life writing and oral testimonies I examine the ways in which people accessed everyday transport over the past two centuries. In the early nineteenth century mobility options were limited and most people travelled in similar ways, though the rich always had access to the fastest and most comfortable transportation. From the mid-nineteenth century the railways provided fast travel for most people. Progressively, in the twentieth century British society became car dependent so that those without access to a car were disadvantaged. Such transport-related social exclusion was exacerbated by the denuding of public transport, and by heightened expectations for mobility which often could not be achieved. It is argued that a return to a less differentiated mobility system could increase transport-related social inclusion.
\end{abstract}

\section{Keywords}

Britain; historical perspective; mobility; social inclusion; transport policies; travel diaries

Issue

This article is part of the issue "Transport Policy and Social Inclusion", edited by Miriam Ricci, Graham Parkhurst and Juliet Jain (University of the West of England, UK).

(C) 2016 by the author; licensee Cogitatio (Lisbon, Portugal). This article is licensed under a Creative Commons Attribution 4.0 International License (CC BY).

\section{Introduction and Context}

Social inclusion and exclusion have figured prominently on both political and social agendas in twenty-first century Britain, with numerous reports highlighting the continuing nature and implications of social exclusion. Although not always explicitly highlighted, exclusion from travel and transport lies at the heart of most of the issues that are discussed. For instance, the Joseph Rowntree Foundation (2000) identified four dimensions of exclusion: 'impoverishment, or exclusion from adequate income or resources; labour market exclusion; service exclusion; and exclusion from social relations'. Lack of access to transport contributes significantly to all these issues. Several studies have focused specifically on transport and social exclusion, with the Social Exclusion Unit report (2003) highlighting the issues and proposing an agenda for planning authorities to tackle the problem. However, a decade later there was little sign of significant change as demonstrated by a Sustrans report (2012) which showed that some 1.5 million people in Britain were experiencing serious transport poverty which cut them off from employment and services. This was defined as experiencing a combination of low household income which made running a car difficult, living more than a mile from the nearest bus or railway station, and living in areas where it takes more than an hour to access essential services by public transport, cycling or on foot. The persistent nature of transport-based social exclusion has also been highlighted in recent academic studies (Hine, 2012; Lucas, 2012; Mattioli, 2014). However, one dimension that has been lacking from most recent research and policy papers is an historical perspective. This paper seeks to redress the balance by demonstrating that an understanding of the ways in which transport-related social inclusion and exclusion have changed over time can inform twenty-first century transport policies.

An historical dimension is rarely considered in any arena of contemporary policy, although some histori- 
ans have begun to highlight the relevance of an historical perspective (Guldi \& Armitage, 2014; History and Policy, n.d.). With respect to transport, Colin Divall and colleagues have recently focused on the ways in which an understanding of transport history can inform current policy (Divall, 2011, 2015; Divall, Hine, \& Pooley, 2016), but for the most part present-day policies seem to be formulated in an historical vacuum. It is not always easy to identify relevant data and demonstrate past trends and interventions that could be relevant today. In the context of social inclusion and exclusion this is further complicated by the complexity of the issues involved. Social exclusion is a multi-dimensional process (Popay et al, 2008): gaining good data on a complex range of issues, and untangling their interrelations in an historical context, can be daunting. Nonetheless, I suggest that it is possible to construct an argument about social inclusion in Britain that does have a strong historical dimension. All the complexities and contradictions that beset the analysis of transportrelated social exclusion in a contemporary context also apply to the past. For instance, principles of social justice and environmental justice do not sit comfortably together, as social justice demands enabling maximum access to the fastest and most convenient forms of transport (for most people today motor vehicles) whereas environmental justice would require strict controls on such vehicles. As personal transport has become faster and more convenient it has also produced more pollutants, causing harm to both global and local environments and to individual health and quality of life for those most affected, usually those with least access to fast and convenient transport (Lucas, 2004, 2006; Pooley, 2016). Transport-related social exclusion has never been solely about transport itself, and often is more properly explained by associated non-transport factors and, particularly, by issues of power, accessibility and choice. Thus in rural areas, lacking most services, transport deprivation and 'forced' car ownership are well documented (Ahern \& Hine, 2012; Currie et al., 2009; Johnson, Currie, \& Stanley, 2010; Shergold \& Parkhurst, 2012), but those with the money, time and good health to be able to drive have the luxury of choosing to live in an attractive rural environment while also accessing all the services they need. Only those whose mobility is constrained by poverty, ill health or other factors experience transport-related social exclusion. Even living close to services and facilities does not guarantee access. For instance, while distance and travel costs may be a disincentive for using health services for some, for others inconvenient opening hours, feelings of alienation or perceived social and cultural differences may be more important (Goddard \& Smith, 2001; Gulliford et al., 2002; Gulliford \& Morgan, 2013; Pooley et al., 2003). Thus social or cultural factors that discourage travelling even short distances to access services may be more im- portant than the cost or convenience of the transport itself. However, separating the effects of such factors is difficult and there is an extensive transport literature discussing mobility and accessibility issues (e.g. Moseley, 1979; Preston \& Rajé, 2007). Additionally, prejudices against, or preferences for, particular forms of transport may cause reluctance to travel if a more acceptable alternative is not available (Beirão \& Cabral, 2007; Pooley \& Turnbull, 2000a). For instance, public transport (especially the bus) is often perceived (particularly by men) as less attractive than driving or even cycling. In situations where the preferred form of transport is not available accessing services may be deferred. Notwithstanding the complexities outlined above, this paper argues that historical evidence suggests that, as transport options have increased, so too has transport-related social exclusion become more common. Although the very rich have always had access to the fastest and most comfortable forms of transport, in the past when modal choices were limited it can be assumed that most people travelled in much the same way. As transport choices increased, and some faster and more convenient modes became more widely available, differences in travel opportunities between different sectors of the population, and different parts of the country, became more obvious. It is argued that in twenty-first century Britain a more socially inclusive transport system, at least in terms of personal mobility, would be one that was more uniform and which therefore offered easy accessibility but less modal choice. Although no doubt perceived as less convenient and congenial for some, differences in travel opportunities and experiences could be minimised. Such a system, if based mainly on lowcarbon public transport, walking and cycling, would also more closely meet the requirements of a more environmentally just transport system.

\section{Sources of Evidence}

Evidence about the patterns and experiences of past mobility is not readily available. Basic information on inter-area journey-to-work flows was first collected in the 1921 census and again in various forms from 1951 (Office for National Statistics: census 1911-2001). More details of everyday movements (including mode, purpose, distance etc.) have been collected in the $\mathrm{Na}$ tional Travel Survey, first conducted in1965-66 and repeated at increasing frequency up to the present (Department for Transport [DfT], 2016a). Additionally, one-off surveys and planning reports from the first half of the twentieth century can provide some information on everyday travel (especially travel to work including the development of workmen's trains in London), but by their nature these are sporadic and do not provide readily comparable data (for instance Abercrombie, 1945; Abernethy, 2015; Barlow, 1940; Jones, 1934; Liepmann, 1944). Prior to the 1920 s little readily- 
available data exists apart from data on passenger loads by mode for municipal providers of trams and motor buses (Barker \& Robbins, 1963; Pooley \& Turnbull, 2000b). However, most of these sources provide only aggregate level data and few give any evidence on the social composition of travellers or the purpose of the journey. In this paper the principal sources consulted are personal diaries, letters, autobiographies, life histories and evidence from oral history. Only by using life writing and, for the more recent past, oral evidence, do we have any chance of reconstructing the range of mundane and everyday journeys that most people regularly undertook.

There are, of course, many problems inherent in using such sources. Their survival is sporadic and random, and it is impossible to assess the representativeness of any set of sources used. All life writing is likely to be biased towards those who had both the literacy and leisure time to write a diary or life history, and some such writing comes from elites who were in the public eye and whose life writing was designed both for public consumption and as a justification of actions taken. Such sources are avoided in this research. There is no way of judging what was included and what was excluded from any form of life writing, and it is likely that unusual events were recorded more assiduously than mundane and repetitive occurrences. Thus a daily journey to work may be rarely commented on but exciting holiday travel recorded in full. In general, diaries which were written up daily, or at least frequently, were more likely to record immediate reactions to everyday occurrences than more considered and retrospective life histories and autobiographies. There is also some evidence of gender differences in life writing, with women more likely to write diaries and men autobiographies (Humphries, 2010, pp. 12-48; Lejeune, 2009; Smith \& Watson, 2010; Vickery, 1998). Similarly, evidence from oral history depends on the skill of the interviewer, the relevance of the questions asked and the memory of the respondent. Recollections may be coloured by information gained later in life and, as with life writing, it is impossible to assess the representativeness of those interviewed (see for instance Fields, 1989; Perks, 1992; Ritchie, 2014; Thompson, 2000; Thomson, Frisch, \& Hamilton, 1994).

Research reported in this paper draws mainly on evidence collected from three separate research projects concerned with different aspects of everyday mobility in the past and the present. Each has been reported elsewhere and only the briefest of details are presented here. First, on-going research is using a range of life writing (diaries, letters, life histories) to examine aspects of everyday life, including mobility, in Britain from circa 1800 to 1950 (Pooley \& Pooley, 2015). Analysis of these diaries provides the basis for most of the discussion of social inclusion and transport prior to the availability of oral evidence and more widely-available twentieth-century sources. Second, research carried out in the 1990s on the journey to work in Britain in the twentieth century collected oral and survey evidence from three large cities (Glasgow, Manchester and London) on the ways in which travel to work has evolved over a century (Pooley, Turnbull, \& Adams, 2005). This source is used for much twentiethcentury evidence. Finally, more recent research on sustainable urban travel, especially walking and cycling, provides data on contemporary mobility patterns and their implications. A large database of oral evidence was collected from four English urban areas (Lancaster, Leeds, Leicester, Worcester) during 2008-11, and is fully reported in Pooley et al. (2013). Although none of these projects originally had social inclusion/exclusion as a main focus, and care must be exercised when making generalisations from a small body of data, all provide data that can be used productively to demonstrate the ways in which changing travel opportunities and experiences have affected access to everyday travel and transport over the past two centuries. Due to constraints of space only a small sample of the evidence available can be quoted here.

\section{Before the Railway}

In nineteenth-century Britain the railways provided a transport revolution at least as significant as the motor car in the first half of the twentieth century and lowcost air travel in the late-twentieth century (Kellett, 1969; Perkin, 1971; Simmons, 1968, 1986). By the 1850s most major cities, and many smaller settlements, were connected into the rail network, but prior to this the options for travel within Britain were limited. Movement was either by road (on foot, on horseback, in a farmer's or carter's waggon, by mail coach or in a private carriage), or on water (by canal barge or on a coastal vessel) (Albert, Aldcroft, \& Freeman, 1983; Dyos \& Aldcroft, 1969). All were relatively slow, and most meant that the traveller experienced some discomfort from the weather, and occasionally on poorly regulated and minimally-maintained roads, some danger from highwaymen or accidents. There were improvements in both the speed and safety of vehicles before the mid-nineteenth century as major roads came under the control of Turnpike Trusts, with improved surfaces but a toll to pay, and with improvements to the design of carriages. However, the fastest, most comfortable and most convenient means of transport could for the most part be accessed only by an affluent minority, with the bulk of the population travelling on foot, cart or, occasionally for longer journeys, by mail coach, though access to a horse would have been more widespread in rural than in urban areas (Albert, 1972; Bogart, 2005; Chartres \& Turnbull, 1983; Freeman, 1980; Pawson, 1977). Thus, although there were certainly both social and spatial inequalities 
in access to travel and transport, for the vast majority of the population mobility experiences were quite similar. In this sense it can be argued that levels of transportrelated social exclusion were relatively low or, to put it a different way, most people were equally excluded from the fastest and most comfortable forms of transport.

Scarce evidence from life writing in the eighteenth and early-nineteenth centuries confirms the extent to which travel was usually slow and potentially uncomfortable but was also taken for granted as the normal way of moving from one place to another. For instance, when Ellen (Nelly) Weeton, mistress in a small village school in South Lancashire, decided to move to Liverpool in 1808, she travelled with minimal belongings first on foot (walking some $18 \mathrm{~km}$ on the first day) and then another $5.5 \mathrm{~km}$ to catch the Wigan Packet boat to Liverpool along a portion of the Leeds-Liverpool canal. Her journey was recorded in a series of letters she sent to friends and relatives. Relevant extracts include: 'On $22^{\text {nd }}$ inst. I left Leigh, walked to Holland, staid all night at my Aunt Barton's, and on the following morning set sail for Liverpool from Apply Bridge; ${ }^{1}$ and 'I left there [Up Holland] the next morning all in the rain, and how it begun to be fair soon after I got into the boat, and what an agreeable sail I had.' ${ }^{2}$ After spending some 15 months in Liverpool Nelly Weeton took a position as a governess to the daughter and companion to the new (young) wife in a wealthy family who lived on the shores of Windermere in Cumbria. On this occasion she travelled by coach, possibly paid for by her new employer (though this is not stated), and she described her journey from Liverpool to Windermere in a series of letters: 'I left Liverpool on Tuesday the $12^{\text {th }}$ and staid all night at Mr Barton's at Walton; the next morning he and I left Preston in the mail and arrived at Kendal soon after two that afternoon. We dined there and then took a post chaise to Mr Peddar's of Dove's Nest twelve miles from Kendal. ${ }^{3}$

More celebrated diarists such as Dorothy Wordsworth have also described both their regular lengthy walks and more occasional longer journeys by coach (Owen, 2003; Wordsworth \& Woof, 2002), and even for the affluent elite journeys by carriage could be uncomfortable and potentially hazardous. Raleigh Trevelyan, the son of Sir John Trevelyan whose London home

\footnotetext{
${ }^{1}$ Letter 80, Ellen Weeton to Miss Bolton, August 27, 1808. Ellen Weeton: Letters to correspondents (Vol 2) October 25, 1807January 3, 1809. Edward Hall Diary Collection, Wigan Archive Service (Leigh). EHC 165a.

2 Letter 81, Ellen Weeton to Mr Weeton, August 31, 1808. Ellen Weeton: Letters to correspondents (Vol 2) October 25, 1807January 3, 1809. Edward Hall Diary Collection, Wigan Archive Service (Leigh). EHC 165a.

${ }^{3}$ Letter 131, from Ellen Weeton to Mr Weeton, December 25, 1809. Ellen Weeton: Letters to correspondents ( Vol 3) January 14, 1809-February 4, 1811. Edward Hall Diary Collection, Wigan Archive Service (Leigh). EHC 165b.
}

was adjacent to New Bond Street, briefly kept a diary as a $13 / 14$ year old schoolboy, and vividly described a winter journey by chaise (part of his trip back to boarding school after the Christmas holidays): 'Got up at 5 was in the chaise at $7 \&$ at St Lawrence in 20 minutes. The snow there is 4 feet deep the road cut through it. Past the turnpike the snow is very deep in a road not used in winter \& a deep chalk pit is full of water on account of the snow having melted into it. In another place the snow is 2 feet deep \& the road cut through it. By 2 mills we went a little out of the road into a field for some way on account of the snow. In another place the snow is 5 feet $\&$ the river has overflowed several fields. The snow by Faversham is $3,4,5,6$ feet $\&$ about the same depth all the way to Gravesend particularly on Chatham hill w[h]ere it is almost 7 feet $\&$ the road cut through almost all the way. Arrived at Charlton at 6 PM (when we dined) having had the same chaise all the way from Canterbury with a crack at the bottom you could put your fingers through. ${ }^{4}$ For these diarists at least almost all journeys were undertaken either on foot, by horsedrawn vehicle or on water and, although the rich had more choice and a little more comfort, differences in everyday experiences of travel were relatively small.

\section{Expanded Travel Options in the 19th Century}

From approximately the 1840 s to the early twentieth century travel choices in Britain expanded significantly but, arguably, access to the different forms of transport remained relatively undifferentiated. The growing rail network allowed people to travel long distances more quickly and in greater comfort than before, and although the rich could separate themselves from less wealthy travellers in first-class carriages, railway travel became more affordable than mail coaches had been in the early-nineteenth century. The poorest in society could rarely afford rail travel, and not all locations in Britain were connected into the rail network, but by the 1870s at least travel by train was a real possibility for a large proportion of the population (Divall \& Shin, 2012; Leunig, 2006). Within urban areas walking continued to be important for many, but horse-drawn omnibuses and trams (first steam and then electric) rapidly provided increased travel options for most people. In London in particular, the expanding suburban rail network, both over ground and underground, provided further travel options. Although both the bicycle and the motor car appeared on British roads from the late-nineteenth century, their major impact came later (Armstrong, 2000; Cannadine \& Reeder, 1982; Dyos \& Aldcroft, 1969; Simmons, 1986). Clearly travel experiences for the very rich and the very poor were different, but the increased range of rela-

\footnotetext{
${ }^{4}$ Diary of Raleigh Trevelyan, February 1814, Edward Hall Diary Collection, Wigan Archive Service (Leigh). EHC 191.
} 
tively affordable means of travel over both long and short distances meant that few were excluded from mobility, most locations offered a number of different transport options, and many forms of transport were shared by travellers drawn from a range of social groups. Life writing from the period can again be used to support this argument.

At the time of writing his diary in the midnineteenth century John Leeson was in his 40s, and a relatively affluent manager of property living in central London. With family and friends John Leeson travelled widely through the city and further afield using a variety of forms of transport. Short local journeys (particularly for pleasure) were often undertaken on foot; for longer trips he would often hire a Hansom cab (he did not keep a carriage) but also used the omnibus and local trains. Longer trips out of the capital were mostly by train, though when convenient he also used coastal vessels from the Thames. For much of his everyday travel his experiences would have been little different from those of many other Londoners, including those of much lesser means. For instance, in August 1847 Leeson recorded: 'Mother came home by Railway from Norwich-I met her at the station at 2 of clock. Fred came with her. She looks well pleased with her excursion there and likes Railway travelling; ${ }^{\prime 5}$ and a couple of years later he wrote: 'Left London and I went by Railway from Euston Square to Derby and Ambergate, Matlock, to Buxton, got there at $5 .{ }^{6}$ Many everyday journeys were only recorded on the occasions when something went wrong, but it is clear from John Leeson's diary that bus use was routine. For instance: 'Charlotte lost $£ 3$ in an omnibus, going to her sister's at Walworth;" and 'I slipped down in London-Euston Road-on leaving an Omnibus and sprained my left arm, was confined to the house a few days with the arm in a sling. ${ }^{8}$ Collecting rent from the properties he managed was often combined with social calls, and for such trips he often hired a cab: 'I went to the tenants for the rents-took Mrs L, baby and Kate in the cab with $\mathrm{me} ;{ }^{\prime}$ but holidays on the south coast were usually undertaken by coastal steamer: 'I left London with Mrs Leeson, Lotty and nurse and went from London Bridge by steamer to Margate, took lodgings on the frontstayed there six weeks...a pleasant rural country town with nice walks out of it. ${ }^{\prime 10}$

\footnotetext{
${ }^{5}$ Diary of John Leeson, August 21, 1847, Bishopsgate Institute Archives, London. GDP/ 8.

${ }^{6}$ Diary of John Leeson, August 2, 1849, Bishopsgate Institute Archives, London. GDP/ 8.

7 Diary of John Leeson, February 8, 1851, Bishopsgate Institute Archives, London. GDP/ 8.

8 Diary of John Leeson, March 3, 1860, Bishopsgate Institute Archives, London. GDP/ 8.

${ }^{9}$ Diary of John Leeson, April 17, 1852, Bishopsgate Institute Archives, London. GDP/ 8.

10 Diary of John Leeson, August 5, 1852, Bishopsgate Institute
}

John Lee, born in 1842, was a young apprentice draper living in north Lancashire when he wrote his surviving diary in the mid-nineteenth century. Although of much lesser means than John Leeson, he travelled in much the same way as his London-based contemporary. Short trips made by Lee were usually on foot, longer journeys by train, with some use of bus or tram when available. He travelled frequently and apparently without significant constraints. There is certainly no indication that he experienced any transport-related social exclusion despite his young age and relatively limited finances. For instance, in 1862 he made the short trip from south Lancashire to his home town of Burnley in north Lancashire by rail: 'Went by the first train to Burnley to get some of my school books \&c out of my large box and a few other things for the Bazaar which we are preparing for in Heywood. ${ }^{11}$ However he usually chose the cheapest means of travel as indicated by an entry for later the same year: 'Stayed with aunt till noon, then I took the half past 12 train to Heywood. I was disappointed in finding that it was a second class train instead of a third as the Time Table stated.' ${ }^{12}$ On occasion, old and new forms of transport could interact as when he missed the train and had to resort to horse-drawn transport: 'Got up to go by the six o'clock train to Ripon, but I was about five minutes too late. I fortunately got to ride in a dray; ${ }^{13}$ but when the opportunity arose he also sampled the newest transport available as on a visit to Birkenhead on Merseyside: 'Train to Liverpool, dinner with Aunt and Uncle Walter. Over to Tranmere, walked from there to Birkenhead and got into one of the Americain [sic] Railway carraiges [sic], that have just been made here to run through the streets on rails. ${ }^{14}$

In small towns and rural areas old and new forms of transport continued to interact much longer than in larger urban settlements. Although by the 1880 s the railway had reached many rural locations, travel to and from a railhead was usually on foot or by cart. Mary Ann Prout (born 1861) lived with her parents in Cornwall when she wrote a diary in 1882 . Her father was a coal merchant with part ownership of a coal vessel that traded out of Perranporth, and Mary, her family and visitors, travelled by a mixture of rail, cart and on foot. The nearest station was about eight kilometres away (a distance that was comfortably walked when necessary) and the nearest town (Truro) some $14 \mathrm{~km}$. Necessity meant that most people travelled in similar ways and, although transport was probably a little slower and less convenient than in large urban areas, the diarists studied were not prevented from undertaking everyday tasks or longer journeys by a lack of transport. Rural

Archives, London. GDP/ 8.

11 Diary of John Lee, April 1, 1860, Private collection.

12 Diary of John Lee, October 15, 1860, Private collection.

13 Diary of John Lee, August 25, 1859, Private collection.

14 Diary of John Lee, October 14, 1860, Private collection. 
travel in the 1880s is illustrated by the following diary extracts: 'Mother sent Telegram to Truro for Father to meet Mr Brunt at Scorrier and sent Roberts's trap to station for them. They went from Scorrier to Perran to see the Willie [a boat] and then came back here...Mr Brunt walked to Chacewater station;'15 'Mr Henwood left about dinner time. Mrs Mitchel from Hayle came in just before he left she walked from Scorrier station this afternoon...Father has left this evening in the Willie for Padstow;' 16 'Father and me went to Truro today the Buss [sic] was very full. I bought a hat, window curtains and several other things. ${ }^{17}$ Despite relative rural isolation there is little sense that Mary Ann Prout and others mentioned in her diary experienced significant transport-related social exclusion.

\section{The rise of the Motor Vehicle in the 20th Century}

Twentieth-century travel in Britain was dominated by the rise of the motorised vehicle, though with a significant subsidiary role for the bicycle in mid-century. In 1920 there were 591,000 registered motor vehicles in Britain, rising to $3,970,000$ in 1950 and $28,897,600$ by the year 2000. Most significantly, in 1920 private cars accounted for only 31.6 per cent of registered vehicles (38.6 per cent were motor cycles and scooters), but by 1950 cars formed almost half of all registered vehicles and in 200080.3 per cent (DfT, 2016c). The story of the twentieth century is not just that of the rise of the motor vehicle but, especially, that of the private motor car. By 2000 there was almost one registered private car for every household in Britain. However, cars were not distributed evenly across the population with 26.8 per cent of households in England having no car while 29.5 per cent had access to two cars or more in 2001 (Office for National Statistics [ONS], n.d.-a). In addition to the private car twentieth-century travellers did have a wide range of other options if they chose to use them. The Victorian railway network remained at approximately the same extent until the reductions of the 1960s, longdistance motor coach services provided an alternative to rail travel from the 1920s, trams and motor buses could provide a dense network of services in urban areas, and for many men in particular the bicycle provided a high degree of personal mobility over short to medium distances, especially in the mid-twentieth century (Dyos \& Aldcroft, 1969; Hibbs, 1989; Pooley et al., 2005). What impact did such changes have on transport-related social exclusion and inclusion in Britain? Selected life writing and oral histories can again be used to explore the eve-

\footnotetext{
15 Diary of Mary Ann Prout, April 22, 1882, Bishopsgate Institute Archives, London. GDP/58.

16 Diary of Mary Ann Prout, May 8, 1882, Bishopsgate Institute Archives, London. GDP/58.

17 Diary of Mary Ann Prout, May 17, 1882, Bishopsgate Institute Archives, London. GDP/58.
}

ryday experiences of travel in the twentieth century.

For at least the first 50 years of the twentieth century car ownership remained restricted to the more affluent, and even those who did own a car rarely used it for mundane everyday trips (O'Connell, 1998). Private motor vehicles were primarily reserved for leisure activities and special occasions. Ida Berry (born 1884) lived with her widowed mother in south Manchester and kept a (surviving) diary from 1902-07. Though living comfortably (she did not work), she recorded no occasions when she rode in a car, and only rarely mentioned male acquaintances that did have access to a car in the first decade of the twentieth century. When recorded, car rides were always for leisure activities, as on this occasion when she and her sister met a male friend in a car as they returned from a cycle ride: 'As we came home we met Harry, motoring, so he turned back and rode between us down Northen Grove, and we had a little chat at the gate. ${ }^{18}$ Similarly, in the 1920s in London the much more affluent junior lawyer Gerald Gray Fitzmaurice (born 1901) also did not have access to a car and only rode with friends for leisure and pleasure, as on this occasion in 1926: 'Staying weekend with the Van Lessens to celebrate Gladys's and my joint birthdays. Yesterday we went for such a lovely drive in Prue's new car, a 5 seater Fiat Saloon, a sweet little thing...Prue drove so well. ${ }^{19}$ Oral evidence from the mid-twentieth century tells a similar story as stated by respondents in Manchester and London: 'If you had access to a car at that stage...you would have used that for leisure only. It would not have occurred to you to use it for work' (Interview RJ04, Manchester, male, 1950s); 'Now taking the car involved driving to the Blackwall tunnel and going round that way, so I would never take the car just to go to work. I would only take it if I was doing something else in the evening' (Interview RJ43, London, male, 1950s). ${ }^{20}$

The ability to make such choices about car use, or to live car-free, was made possible in the first half of the twentieth century by continued provision of good public transport in both rural and urban areas, together with a willingness to walk or cycle for many shorter journeys. Catherine Gayler (born 1919) was a schoolgirl living with her parents in rural Lincolnshire when she kept a diary in the 1930s. Her father did not have a car and all travel was by bike, bus or on foot. Her most frequent trips were the approximately ten kilometre journey from home to Grantham (where she went to school), and the $21 \mathrm{~km}$ to her grandmother's house. On

\footnotetext{
18 Diary of Ida Berry, March 27, 1905, Bishopsgate Institute Archives, London. GDP/28.

${ }^{19}$ Diary of Gerald Gray Fitzmaurice, October 24, 1926, Bishopsgate Institute Archives, London. GDP/52.

${ }^{20}$ Oral history data in this section was collected as part of a project on the journey to work in twentieth-century Britain, funded by The Leverhulme Trust (1996-99).
} 
school days she mostly used the bus, but both journeys were also regularly undertaken by bike: 'Didn't get up very early in morning and biked over to grannies with Mum in afternoon. It rained quite hard coming back. Got home just after six.' ${ }^{21}$; 'Went to Grantham on 1 bus back on the 4 to do Xmas shopping. ${ }^{22}$ Even in the much more remote Eskdale valley in Cumbria, Jill Caldwell (born 1937) had numerous travel options as a teenage girl in the 1950s. Her father and some other male acquaintances had cars in which she sometimes cadged a lift, but she mostly travelled by bus, train or (less frequently) by taxi, bike or on foot. She often juggled different forms of transport but always seemed to complete a journey without undue difficulty, as in this instance when returning from a shopping trip to Carlisle: 'I'd no sooner got to June's than we were off shopping and we were in plenty of time for the train at Carlisle....We managed to catch a bus to Gosforth and I also managed to persuade June that a taxi was a NECESSITY if I was to keep alive. ${ }^{23}$ Urban dwellers had even more transport choices, and oral history respondents regularly travelled by tram, bus, bike, train or on foot in mid-century. Although not all travel was trouble free, three brief examples show the degree to which easy urban travel was taken for granted by most people: 'Well tram cars was....the mode of transport....That was the normal mode of transport and it was very cheap in these days' (Interview RJ49, Glasgow, male, 1930s); 'Well I had ridden a bicycle to school and it was just slightly easier. I didn't have the long walk to the bus stop...I didn't have to change buses, it was just easier to go on the bike' (Interview RJ03, London, female, 1950s); 'Yes [there was public transport], but I could walk as quickly then. Those were the days!' (Interview RJ15, Manchester, female, 1930s).

However, by mid-century changes were occurring that by the 1960s led to a large increase in everyday car use as well as car ownership. Many factors drove increased car dependence, including greater affluence, but for routine travel to and from work the dispersion of employment to the periphery of cities was significant. As work places became less easily accessed by public transport the car rapidly became the preferred means of commuting. This was stated by oral history respondents in Manchester and Glasgow: 'Yes, I got a car at that point because to travel to $x$ was quite awkward. To do it by public transport would mean...a bus journey, an underground journey, and another bus journey...so it really wasn't terribly convenient, so I'd managed to accrue a little capital and I bought a car'

\footnotetext{
${ }^{21}$ Diary of Catherine Gayler, September 29, 1934, Bishopsgate Institute Archives, London. GDP/16.

22 Diary of Catherine Gayler, December 21, 1934, Bishopsgate Institute Archives, London. GDP/16.

${ }^{23}$ Diary of Anne (Jill) Caldwell, April 28, 1952, Bishopsgate Institute Archives, London. GDP/1.
}

(Interview RJ39, male, Glasgow, 1950s); 'Yes I got my first car in 1954....I didn't want a car to travel through Manchester to get to Blackley, but I knew when I was offered this job at Alderley Edge that I would have to do it because there was no cross-country transport at all. It was just hopeless, so I decided to have a car' (Interview RJ15, Manchester, female, 1950s). The continued dominance of car-use for most everyday travel, first predominantly by men but by the later twentieth century also by many women, together with the erosion (and in some rural areas often complete removal) of public transport in the later twentieth century is well documented (Docherty \& Shaw, 2008; Sheller \& Urry, 2000; Urry, 2004). As one London respondent stated: 'The trouble is my little eight-minute journey, to do it by public transport would be two buses...there's no direct route for me from work....It's door to door, it's just convenience' (Interview RJ92, London, male, 1990s). Gradually, travelling by any means other than a private car became more difficult and less attractive, and those without access to a car (especially in areas with the most denuded public transport) increasingly found their lives restricted by lack of everyday transport.

\section{Conclusions: Into the 21st Century}

In theory the twenty-first century traveller in Britain has more transport options than ever before, leading to enhanced expectations that movement both within Britain and internationally should be quick, easy and relatively cheap. Certainly the advent of low-cost airlines has enabled unprecedented levels of international travel for many (Lyth, 2016), and new mobile communication systems have further widened horizons and increased connectivity (Büscher, Urry, \& Witchger, 2011). We live in an increasingly mobile world in which there is an assumption that travel and communication over both long and short distances should be unrestricted (Larsen, Urry, \& Axhausen, 2007; Urry, 2007). However, one consequence of such high expectations is that disappointment and frustration is that much greater if expectations are not fulfilled. Those unable to participate fully in a highly mobile twenty-first century society are likely to experience both absolute and relative transport-related social exclusion, leading to reduced employment and social opportunities and, potentially, to ill-health due to feelings of frustration and isolation. While health effects of isolation have been most extensively studied among older people (Luo, Hawkley, Waite, \& Cacioppo, 2012; Victor \& Bowling, 2012), transport-related social exclusion can cause problems for any age group. Such sentiments were expressed by a number of interview respondents in a recent study of everyday travel in four English towns. ${ }^{24}$

${ }^{24}$ Interviews cited in this section were carried out as part of an EPSRC-funded research project on walking and cycling, 2008-11. 
For instance: 'People still assume that there's something wrong with you if you don't drive' (Interview P121, Leeds, married couple interview); 'Personal safety is an issue and the car, people feel safe in their own car' (Interview P139, Leicester, male); 'Living without a car would be a high maintenance lifestyle' (Interview P80, Worcester, family interview). Although many respondents did seek to minimise car use (and some lived car-free), others clearly articulated their perceived need to have access to a car when needed.

Seen through an historical lens travel in the twentyfirst century is something of a paradox. Travel and communication is easier than it has ever been and most people in Britain have access to transport that would have been beyond the imagination of most two centuries ago. However, at the same time a combination of heightened expectations and car dominance has meant that those who cannot access fast and convenient travel may experience some effects from transport-related social exclusion. In the past, when travel options were fewer, expectations were lower and travel experiences more uniform across much of the population. In 2011 approximately one quarter of English households did not have access to a car or van, but access to appropriate transport depends on more than just household car ownership. In large urban areas which have retained good public transport networks (especially London) a car is not needed for most everyday journeys. In contrast in many small towns and rural areas a car is essential. Age restrictions on car driving were enforced in Britain from 1930 and a driving test introduced in 1935 (Driver and Vehicle Standards Agency, 2016); thus in contrast to almost all other forms of transport certain groups are by definition excluded from driving. In all locations the young and the old (often excluded from driving by illhealth) will be most dependent on forms of transport other than the car, or on lifts from those who can drive. Although the gap is narrowing, women are also less likely to have a driving licence than men. In 1975-76 only 29 per cent of females aged 17 or over had a driving licence compared to 69 per cent of men. By 2014 the figures were 67 per cent and 80 per cent respectively (DfT, 2016c). To some extent variations in access to transport and mobility by location, age, gender and income have always been present but, as demonstrated by the evidence presented from life writing and oral testimonies, for the most part transport choices and opportunities in the past appear to have been more inclusive than is the case today. It can be argued that a society which is less car-dependent, and in which there are either fewer choices (for instance through greater restrictions on car use) or more evenly distributed choices, can produce greater transport-related social inclusion.

\section{Acknowledgements}

Thanks to Jean Turnbull for assistance with collecting oral life history data, to Dave Horton, Griet Scheldeman, Caroline Mullen and Tim Jones for the collection of interview data, and Marilyn Pooley for assistance with transcribing diaries.

\section{Conflict of Interests}

The author declares no conflict of interests.

\section{References}

Abercrombie, P. (1945). Greater London plan 1944. London: HMSO.

Abernethy, S. T. (2015). Opening up the suburbs: Workmen's trains in London 1860-1914. Urban History, 42(1), 70-88.

Ahern, A., \& Hine, J. (2012). Rural transport-Valuing the mobility of older people. Research in Transportation Economics, 34(1), 27-34.

Albert, W. (1972). The Turnpike road system in England: 1663-1840. Cambridge: Cambridge University Press.

Albert, W., Aldcroft, D., \& Freeman, M. (1983). Transport in the industrial revolution. Manchester: Manchester University Press.

Armstrong, J. (2000). From Shillibeer to Buchanan: Transport and the urban environment. In $\mathrm{M}$. Daunton (Ed.), The Cambridge urban history of Britain 1840-1950 (pp. 229-260). Cambridge: Cambridge University Press.

Barker, T. C., \& Robbins, M. (1963). A history of London transport: The nineteenth century. London: Allen \& Unwin.

Barlow, S. (1940). Report of the Royal Commission on the distribution of the industrial population. London: HMSO.

Beirão, G., \& Cabral, J. (2007). Understanding attitudes towards public transport and private car: A qualitative study. Transport Policy, 14(6), 478-489.

Bogart, D. (2005). Turnpike trusts and the transportation revolution in 18th century England. Explorations in Economic History, 42(4), 479-508.

Büscher, M., Urry, J., \& Witchger, K. (Eds.) (2011). Mobile methods. London: Routledge.

Cannadine, D., \& Reeder, D. (Eds.). (1982). Exploring the urban past: Essays in urban history by H.J. Dyos. Cambridge: Cambridge University Press.

Chartres, J., \& Turnbull, G. (1983). Road transport. In W. Albert, D. Aldcroft, \& M. Freeman (Eds.), Transport in the industrial revolution (pp. 64-99). Manchester: Manchester University Press.

Currie, G., Richardson, T., Smyth, P., Vella-Brodrick, D., Hine, J., Lucas, K., . . . Stanley, J. (2009). Investigating links between transport disadvantage, social exclusion and well-being in Melbourne-Preliminary results. Transport Policy, 16(3), 97-105.

Department for Transport. (2016a). National Travel Survey. Retrieved from https://www.gov.uk/government 
/collections/national-travel-survey-statistics

Department for Transport. (2016b). National Travel Survey 2014. Retrieved from https://www.gov.uk/govern ment/statistics/national-travel-survey-2014

Department for Transport. (2016c). Vehicle Statistics, Table VEH0103. Retrieved from https://www.gov.uk/ government/statistical-data-sets/veh01-vehicles-regi stered-for-the-first-time

Divall, C. (2011). Transport history, the usable past and the future of mobility. In M. Grieco \& J. Urry (Eds.), Mobilities: New perspectives on transport and society (pp. 305-319). Farnham: Ashgate.

Divall, C. (2015). Introduction. In C. Divall (Ed.), Cultural histories of sociabilities, spaces and mobilities (pp. 316). London: Pickering and Chatto.

Divall, C., Hine, J., \& Pooley, C. (Eds.). (2016). Transport policy: Learning lessons from history. Farnham: Ashgate.

Divall, C., \& Shin, H. (2012). Cultures of speed and conservative modernity: Representations of speed in Britain's railway marketing. In B. Fraser \& S. Spalding (Eds.), Trains, culture, and mobility: Riding the rails (pp. 3-26). Plymouth: Lexington.

Docherty, I., \& Shaw, J. (Eds.) (2008). Traffic jam: Ten years of 'sustainable' transport in the UK. Bristol: Policy Press.

Driver and Vehicle Standards Agency. (2016). History of road safety, the highway code and the driving test. GOV.UK. Retrieved from https://www.gov.uk/govern ment/publications/history-of-road-safety-and-the-dri ving-test/history-of-road-safety-the-highway-codeand-the-driving-test

Dyos, H. J., \& Aldcroft, D. (1969). British transport: An economic survey from the seventeenth century to the twentieth. Leicester: Leicester University Press.

Fields, K. (1989). What one cannot remember mistakenly. Oral History, 17(1), 44-53.

Freeman, M. (1980). Road transport in the English Industrial Revolution: An interim reassessment. Journal of Historical Geography, 6(1), 17-28.

Goddard, M., \& Smith, P. (2001). Equity of access to health care services: Theory and evidence from the UK. Social Science \& Medicine, 53(9), 1149-1162.

Guldi, J., \& Armitage, D. (2014). The history manifesto. Cambridge: Cambridge University Press.

Gulliford, M., Figueroa-Munoz, J., Morgan, M., Hughes, D., Gibson, B., Beech, R., \& Hudson, M. (2002). What does 'access to health care' mean? Journal of health services research \& policy, 7(3), 186-188.

Gulliford, M., \& Morgan, M. (Eds.). (2013). Access to health care. London: Routledge.

Hibbs, J. (1989). The history of British bus services. Newton Abbot: David \& Charles.

Hine, J. (2012). Mobility and transport disadvantage. In M. Grieco \& J. Urry (Eds.), Mobilities: New perspectives on transport and society (pp. 21-40). Farnham: Ashgate.
History and Policy. (n.d.). Retrieved from http://www. historyandpolicy.org

Humphries, J. (2010). Childhood and child labour in the British industrial revolution. Cambridge: Cambridge University Press.

Johnson, V., Currie, G., \& Stanley, J. (2010). Measures of disadvantage: Is car ownership a good indicator? Social Indicators of Research, 97(3), 439-50.

Jones, D. C. (1934). The social survey of Merseyside (3 volumes). Liverpool: Liverpool University Press.

Joseph Rowntree Foundation. (2000). Poverty and social exclusion in Britain. Retrieved from http://www.jrf.or g.uk/publications/poverty-and-social-exclusion-britain

Kellett, J. (1969). The impact of railways on Victorian cities. London: Routledge and Kegan Paul.

Larsen, J., Urry, J., \& Axhausen, K. (2007). Mobilities, networks, geographies. Aldershot: Ashgate.

Lejeune, P. (2009). On diary. Honolulu: University of Hawaii Press.

Leunig, T. (2006). Time is money: A re-assessment of the passenger social savings from Victorian British railways. The Journal of Economic History, 66(3), 635673.

Liepmann, K. (1944). The journey to work: Its significance for industrial and community life. London: K. Paul, Trench, Trubner.

Lucas, K. (2004). Running on empty: Transport, social exclusion and environmental justice. Bristol: Policy Press.

Lucas, K. (2006). Providing transport for social inclusion within a framework of environmental justice in the UK. Transportation Research A, 40(10), 801-809.

Lucas, K. (2012). Transport and social exclusion: Where are we now? Transport policy, 20, 105-113.

Luo, Y., Hawkley, L., Waite, L., \& Cacioppo, J. (2012). Loneliness, health, and mortality in old age: A national longitudinal study. Social Science \& Medicine, 74(6), 907-914.

Lyth, P. (2016). Plane crazy Brits: Aeromobility, climate change and the British traveller. In C. Divall, J. Hine, \& C. Pooley (Eds.), Transport policy: Learning lessons from history (pp. 171-184). Farnham: Ashgate.

Mattioli, G. (2014). Where sustainable transport and social exclusion meet: Households without cars and car dependence in Great Britain. Journal of Environmental Policy \& Planning, 16(3), 379-400.

Moseley, M. (1979). Accessibility: The rural challenge. London: Methuen.

O'Connell, S. (1998). The car and British society: Class, gender and motoring, 1896-1939. Manchester: Manchester University Press.

Office for National Statistics. (n.d.-a). Census 1911-2001. Retrieved from http://www.ons.gov.uk/ons/guidemethod/census/2011/how-our-census-works/aboutcensuses/census-history/200-years-of-thecensus/census-1911-2001/index.html

Office for National Statistics. (n.d.-b). Census of England 
and Wales 2001. Retrieved from http://www.neigh bourhood.statistics.gov.uk/dissemination

Owen, S. (2003). Nineteenth-century Lake District diaries: Personal experiences of landscape and sense of place. Unpublished PhD thesis, Lancaster University.

Pawson, E. (1977). Transport and economy: The turnpike roads of eighteenth century Britain. New York: Academic Press.

Perkin, H. (1971). The age of the railway. Newton Abbot: David and Charles.

Perks, R. (1992). Oral history: Talking about the past. London: Historical Association.

Pooley, C. (2016). Balancing social justice and environmental justice: Mobility inequalities in Britain since circa 1900. In C. Divall, J. Hine, \& C. Pooley, C. (Eds.), Transport Policy: Learning lessons from history (pp. 47-64). Farnham: Ashgate.

Pooley, C., Briggs, J., Gatrell, T., Mansfield, T., Cummings, D., \& Deft, J. (2003). Contacting your GP when the surgery is closed: Issues of location and access. Health \& Place, 9(1), 23-32.

Pooley, C., Jones, T., Tight, M., Horton, D., Scheldeman, G., Mullen, C., ... Strano, E. (2013). Promoting walking and cycling: New perspectives on sustainable travel. Bristol: Policy Press.

Pooley, C., \& Pooley, M. (2015). 'Mrs Harvey came home from Norwich...her pocket picked at the station and all her money stolen': Using life writing to recover the experience of travel in the past. Journal of Migration History, 1(1), 54-74.

Pooley, C., \& Turnbull, J. (2000a). Modal choice and modal change: The journey to work in Britain since 1890. Journal of Transport Geography, 8(1), 11-24.

Pooley, C., \& Turnbull, J. (2000b). Commuting, transport and urban form: Manchester and Glasgow in the mid-twentieth century. Urban History, 27(3), 360383.

Pooley, C., Turnbull, J., \& Adams, M. (2005). A mobile century? Changes in everyday mobility in Britain in the twentieth century. Aldershot: Ashgate.

Popay, J., Escoral, S., Hernández, M., Johnston, H., Mathieson, J., \& Rispel, L. (2008). Understanding and tackling social exclusion: Final report of the World Health Organization. Social Exclusion Knowledge
Network. Retrieved from http://www.who.int/so cial_determinants/knowledge_networks/final_repor ts/sekn_final\%20report_042008.pdf?ua=1

Preston, J., \& Rajé, F. (2007). Accessibility, mobility and transport-related social exclusion. Journal of Transport Geography, 15(3), 151-160.

Ritchie, D. (2014). Doing oral history. Oxford: Oxford University Press.

Sheller, M., \& Urry, J. (2000). The city and the car. International Journal of Urban and Regional Research, 24(4), 737-757.

Shergold, I., \& Parkhurst, G. (2012). Transport-related social exclusion amongst older people in rural Southwest England and Wales. Journal of Rural Studies, 28(4), 412-421.

Simmons, J. (1968). The railways of Britain: An historical introduction. London: Macmillan.

Simmons, J. (1986). The railway in town and country, 1830-1914. Newton Abbot: David and Charles.

Smith, S., \& Watson, J. (2010). Reading autobiography. A guide for interpreting life narratives. Minneapolis: University of Minnesota Press.

Social Exclusion Unit. (2003). Making the connections: Final report on transport and social exclusion. London: Office of the Deputy Prime Minister.

Sustrans. (2012). Locked out: Transport poverty in England. Sustrans. Retrieved from http://www.sustrans. org.uk/lockedout

Thompson, P. (2000). The voice of the past: Oral history. Oxford: Oxford University Press.

Thomson, A., Frisch, M., \& Hamilton, P. (1994). The memory and history debates: Some international perspectives. Oral History, 22(2), 33-43.

Urry, J. (2004). The 'system' of automobility. Theory, Culture \& Society, 21(4/5), 25-39.

Urry, J. (2007). Mobilities. Cambridge: Polity.

Vickery, A. (1998). The gentleman's daughter: Women's lives in Georgian England. New Haven, CT: Yale University Press.

Victor, C., \& Bowling, A. (2012). A longitudinal analysis of loneliness among older people in Great Britain. The Journal of psychology, 146(3), 313-331.

Wordsworth, D., \& Woof, P. (2002). The Grasmere and Alfoxden journals. Oxford: Oxford University Press.

\section{About the Author}

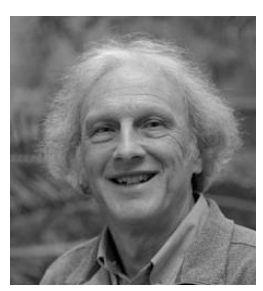

Colin Pooley is Emeritus Professor of Social and Historical Geography at the Lancaster Environment Centre, Lancaster University, UK. His research focuses on the social geography of Britain and continental Europe since circa 1800, with recent projects focused on migration, mobility and sustainable travel. He has published over 100 journal articles and book chapters and 13 books including Promoting Walking and Cycling: New Perspectives on Sustainable Travel (Policy Press, 2013). 